\title{
The other space of social media: Concept study of heterotopia on Instagram
}

\section{Ruang lain di sosial media: Studi konsep heterotopia di Instagram}

\author{
Biko Nabih Fikri Zufar ${ }^{1 \bowtie}$, Eka Kartika Sari² \\ ${ }^{1}$ Department of Sociology, Faculty of Social and Political Sciences, Universitas Gadjah Mada \\ Yogyakarta, 55281, Special District of Yogyakarta Province, Indonesia \\ ${ }^{2}$ Department of Sociology, Faculty of Social and Political Sciences, Universitas Airlangga \\ Surabaya, 60286, East Java Province, Indonesia \\ E-mail of corresponding author: bikonfz@gmail.com.
}

\begin{abstract}
Technological developments in society are separate space into two forms, real space and virtual space. The two meet each other when either individuals or communities use virtual space. Foucault described space to be three forms: dystopia, utopia, and heterotopia. This article aims to explain Instagram as virtual space that intersects real space, forming other spaces in the process. This article uses the perspective of the sociology of space and place while also using Foucault's theory of other space. This study used the qualitative research method with a discourse analysis approach. The finding of this article is that there are six heterotopia principles contained in Instagram's features. The results, Instagram forms other space beyond the activity of uploading photos or videos. Instagram as a real space becomes biased because of heterotopia. Individuals interpret Instagram differently as a place to share. On the contrary, when sharing activities, other individuals may use it for more than just sharing. Instagram has changed its space due to a shift in place use. Instagram can create other spaces besides its original function of uploading photos or videos through the other features on Instagram.
\end{abstract}

Keyword: heterotopia; instagram; discourse analysis

Abstrak

Perkembangan teknologi dalam masyarakat membagi ruang menjadi dua bentuk, ruang nyata dan ruang maya. Keduanya bertemu satu sama lain ketika individu atau komunitas menggunakan ruang virtual. Foucault menggambarkan ruang menjadi tiga bentuk: distopia, utopia, dan heterotopia. Artikel ini bertujuan untuk menjelaskan Instagram sebagai ruang virtual yang bersinggungan dengan ruang nyata, membentuk ruang lain dalam prosesnya. Artikel ini menggunakan perspektif sosiologi ruang dan tempat sekaligus menggunakan teori Foucault tentang ruang lain. Penelitian ini menggunakan metode penelitian kualitatif dengan pendekatan analisis wacana. Temuan artikel ini adalah terdapat enam prinsip heterotopia yang terdapat pada fitur-fitur Instagram. Hasilnya, Instagram membentuk ruang lain di luar aktivitas mengunggah foto atau video. Instagram sebagai ruang nyata menjadi bias karena adanya heterotopia. Setiap orang mengartikan Instagram secara berbeda sebagai tempat untuk berbagi. Sebaliknya, saat berbagi aktivitas, orang lain mungkin menggunakannya untuk lebih dari sekadar berbagi. Instagram telah mengubah ruangnya karena pergeseran penggunaan tempat. Instagram dapat membuat ruang lain selain fungsi aslinya mengunggah foto atau video melalui fitur lain di Instagram.

Kata Kunci: heterotopia; instagram; analisis wacana

\section{Introduction}

Today's technological advances have the effect of changing the form of space into something more abstract. There is no longer the limitation of space as a real form or virtual space. The internet is an entity that is capable of changing this form, moving the realities of space and making real space more layered. This space is referred to as the virtual world. It is a space that in reality has blurred boundaries with space in the real world (Jordan 2009). The internet phenomenon has become a reality in the form of applications on smartphones (Feng 2005). This tangible format allows individuals to communicate with each other in real time via the internet. Even though it is an invisible space, human activities also occur in cyberspace. One of them is Instagram, an application used to share photos and videos widely. Users can share all events in either a photo or video format in the form of electronic data. They can also see other users' events when they are shared in turn. Apart from just sharing, the application can be used for other activities such as communicating through the comments or direct messaging. Phenomena other than sharing events, or events from Foucault's point of view, are referred to as heterotopia.

The concept of heterotopia occurs through Foucault's critique of Rene Descartes' description of space. Rene Descartes said that space is divided into two, namely materialistic-objective and spiritualisticsubjective (Damajani 2008). Materialistic-objective space contains reality and character. On the other hand, spiritualistic-subjective is an intangible or visual space, including ideas, abstractions, and even spirits that are attached to certain areas. The division of the dimensions of space separates the ideas and the physical space. According to Foucault, a space has a relationship with other spaces and the social 
structures in society. They cannot be separated. There are other spaces that can be read when doing a space reading. Foucault defines space into three; real space (dystopia), utopia, and heterotopia (Monita 2010).

Dystopia is a real space. It can also be described a real form of space. It is a representation of reality as a form of human need. Instagram is a human reality that puts everything in its existence on show. This existence is linked to daily activities. Utopia is the shadow or will of the Instagram creator. This could be in the form of ideas or more specifically, the ideas behind the creation of Instagram. Unreal space has direct general relations, or it can even be contrary, with and to real space. Heterotopia is a mixture of both dystopia and utopia, showing the real form of utopia in the process.

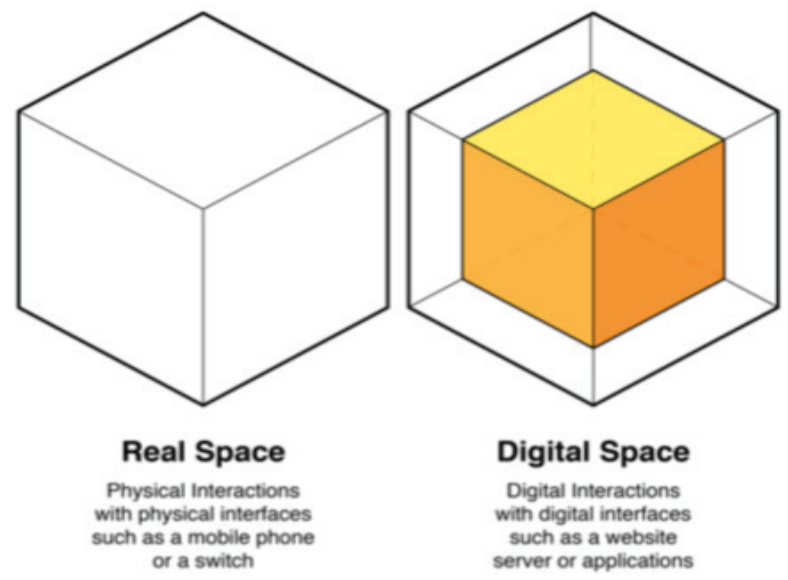

Figure 1.

Imagining digital space as a subset of real space (Akmal \& Coulton 2018) Source: Personal data

Figure 1 explains the position or existence of a room. The goal is to be able to differentiate between real space and digital space. Real space is a form of space that humans can capture empirically. Digital space is in the middle and cannot be separated from real space. It is real and humans can capture it empirically. But the fact arises that it does not really exist. It is only able to be accessed by meeting the prerequisites. Digital space requires media such as a device, a strong signal and an internet quota. If the prerequisites are not met, the digital space will never materialize, meaning that it will never become a human empirical experience. The best way to see virtual space is by dividing the actual space in which there are two realities. However, this reality is still one. According to Tuan's perspective, broadly dividing a space results in it containing a sense of inside and outside (Tuan 1977). Real space is the space outside the digital space, whereas the digital space is the space inside the real space that intersects with the real space. Gadgets are real spaces. On the other hand, Instagram is a digital space that intersects with reality in real space as a form of interaction.

Technology is increasingly developing which adds to the complexity of human interactions in space. In real space and digital space, social events can be divided into public and private social events. The spatial perspective can be divided into public real space, private real space, public digital space, and private digital space. The space remains one and there is a utopia in the real space. Every intersection between the real and digital space produces heterotopia. Instagram becomes a real space when it has been downloaded as an application on a device, but it can still be a digital space when it is still an application that has not yet been downloaded.

To make it easier to analyze and explain the other spaces or heterotopia, this article used the heterotopia concept by Foucault. Figure 2 explains that digital space is a space that overlaps and has no boundaries. Foucault provided six principles regarding heterotopia. The virtual world can also be analyzed using the concept of heterotopia because according to Foucault, space is not limited by geographical boundaries (Foucault 2008). Foucault does not explain this in detail but there is no geographic boundary in this sense so long as there is room for Foucault's heterotopia analysis to be used. One way to explain heterotopia is food. In a food-focused company, there are sustainable and positive business practices. It has an impact on the power structure provided by the food provider in reference to culture, health, and nutritional content (Castro et al. 2018). In addition, there have been several previous studies on Instagram and heterotopia. Instagram is used intensively by educators to engage in knowledge exchange, and this has had an impact on education in the digital era (Carpenter et al. 2020). Instagram can also be used as a method of digital marketing by a company by taking advantage of the features on Instagram (Kusuma 
2018). Heterotopia analysis can also be used to analyze urban spaces and people's behavior. The results in the urban landscapes are interpreted as heterogeneous spaces, and the equality in urban communities is examined (Sudrajat 2012). Furthermore, in general, heterotopia in social media can exist through its functions and capabilities. Social media can be used as an attractive public space as it encourages the users of social media to engage in conversations about the issues in society (Lee \& Wei 2020).

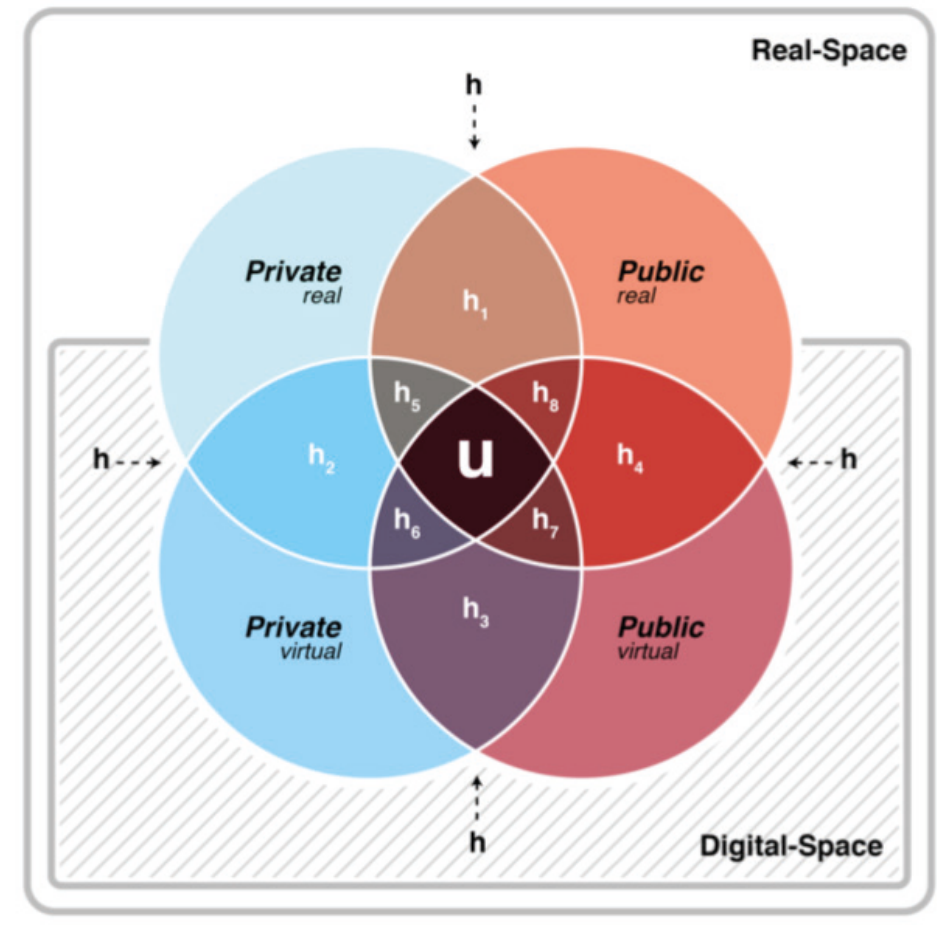

Figure 2.

Philosophical model for inter-spatial interactivity (Akmal \& Coulton 2018) Source: Personal data

This article aimed to explain Instagram as virtual space that also involves other spaces when it intersects with real space. It is interesting to study the phenomenon of other spaces on Instagram through postmodern sociological conceptions, more specifically Foucault's heterotopia concept. This research focuses specifically on the emergence of heterotopia on the social networking application Instagram. This is interesting to study because Instagram is not only a place to upload photos and videos electronically. It has other functions that are generally capable of producing interactions. These other functions will be studied because according to Foucault, another function creates another space, known as heterotopia.

\section{Research Method}

In this article, we wanted to reveal the existence of other spaces on Instagram in depth. This cannot be explained numerically. An explanation is a description of a reality, therefore this article used a descriptive qualitative research method because it aims to explain the other spaces on Instagram. Qualitative research methods are used in research that intends to understand a phenomenon based on the experiences of the research subjects, for example, through their behavior, perception, motivation and actions (Moleong 2003). The hope is to be able to produce articles in a descriptive and holistic manner in the form of words and language. In a natural context, this is done by utilizing various scientific approaches.

This article used a discourse analysis approach. The concept of discourse according to Foucault is a meaning formation activity that is the essence of human relations. It produces big concepts, namely knowledge and power (Foucault 2012). According to Gee, the key to discourse is "confession" (Gee 2005). The unification of language, activities, intelligent, values, convictions, images, objects, instruments, and places in such a way as to prompt the recognition of the person as a certain sort of who (personality) is included in a specific sort (action) within show (Gee 2005). This activity then forms the identity of the subject. The subject must repeat it so then they can be recognized. However, when what is done is quite different from before but the subject is still recognizable, the subject is changing and transforming the discourse. 
This method was chosen because it can be used to study the discourse through the activities on Instagram. Before conducting the study, the author conducted observations on Instagram for 6 months from January 2020 to June 2020. This article used the participant observation method. Participant observation is a method observation where the researcher is also part of and participates in the phenomenon under study (Kawulich 2005). The first step in observing the virtual space, especially one like Instagram, is that everyone must have an account to become a user of Instagram. The observation was conducted using personal accounts that had been made previously. The observations were made by looking at the data according to the six principles of heterotopia. After the data was collected according to needs of the article, the analysis was carried out. The observations were made without classifying the subjects or accounts on Instagram. This was in order to be able to observe the use of space on Instagram by looking at the activities of the subject on Instagram. The subject in question was all things related to Instagram, especially other spaces on Instagram.

Other spaces in Instagram are presented through the representations of constant innovation by Instagram. This innovation is in the form of utilizing the features available on Instagram. The features include cameras, Instagram Stories, Instagram Live, highlights, the feed, filters, captions, comments columns, the buttons for liking and saving photo or video posts, direct messaging, tagging and Sharing. These all represent other spaces where the representation of meaning occurs on Instagram. The meaning representation was then analyzed. The analysis was carried out by looking at the spaces used by the activities on Instagram. These activities were in the form of posting photos, videos, Instagram stories and providing captions that accompany the posts. The posts were then analyzed to determine the meaning that the Instagram content creator wants to convey. The analysis was carried out by not only looking at "images" but also interactions, language, symbols, and the user actions or activities in the Instagram space.

\section{Results and Discussion}

\section{The beginning of Instagram}

Instagram is a social media platform that was founded in 2010 by Kevin Systorm and Mike Krieger. Instagram was created to share photos and videos which can also link to other social media accounts such as Facebook, Twitter, Tumblr and Flickr. The Instagram application can be downloaded from the Apps Store as of 6 October 2010 and from Google Play since April 2012. The emergence of Instagram received a positive response, as can be seen by the large number of users since its initial launch on the Apps Store. As many as 100 million users have since downloaded and registered on the application (Abbott et al. 2013). In 2012, Instagram was bought by Facebook, meaning that the current owner of Instagram is Mark Zuckerberg.

Instagram users can upload photographs and short videos with a maximum duration of 15 seconds (Salomon 2013; Karimkhani et al. 2014). The photos or videos can be selected from the device gallery or they can be taken directly through the Instagram application. This is because Instagram itself has a camera feature that can capture photos and videos (in less than 1 minute if uploaded on the page feed) directly. Figure 3 shows that Instagram also provides photo and video filters that are free to use before uploading. The filters function to adjust the color (tone) of photos and videos. The purpose of filters is to beautify the colors and appearance of the photos and videos before uploading them. The Instagram application users can also correct the size of the photos and videos by cutting them according to their preference. The photos and videos to be uploaded can be given an explanation. A description space will be displayed below the photos and videos after uploading (Huang \& Su 2018). This description serves to explain the photos and videos that are to be uploaded. The photos and videos that will be uploaded can also be used to tag the person in the image. The tagging is done by tabbing the "Tag Person" menu when the photo is to be uploaded. In addition to marking the people who are registered as other Instagram users, photos and videos can be given a location description using the "Add Location" feature tab. Instagram will search for the location. The location description will then appear at the top of the photo or video after being uploaded successfully.

Instagram account owners can link their photos and videos to other social media such as Facebook, Twitter and Tumblr (Kusuma 2018). The option to share or send photos and videos that have been edited on the Instagram application is available before the photos and videos are formally uploaded. The menu display and features described can be seen in the attached image below.

The appearance and space of Instagram has become more varied after being acquired by Mark Zuckerberg. Before being acquired, the features on Instagram looked simpler as a social media place to share photos and videos. However, after being acquired, Instagram's filters and features have become more varied. 
The old Instagram app icon looks like an aesthetic Polaroid camera. The icon symbolizes Instagram as an application for creating and capturing photos and videos in box frames like the photos from a Polaroid camera. After being acquired, the Instagram application icon looks more colorful. The new appearance of the Instagram application signifies the novelty of the new ownership and the diversity of its features. Instagram has been reborn without losing its original function as a social media application where you can upload and view photos and videos. New features have sprung up on the Instagram application. There is now a feature to send uploads (photos or videos) to other Instagram users in the Instagram room. Stories that are private will appear in a Direct Message.

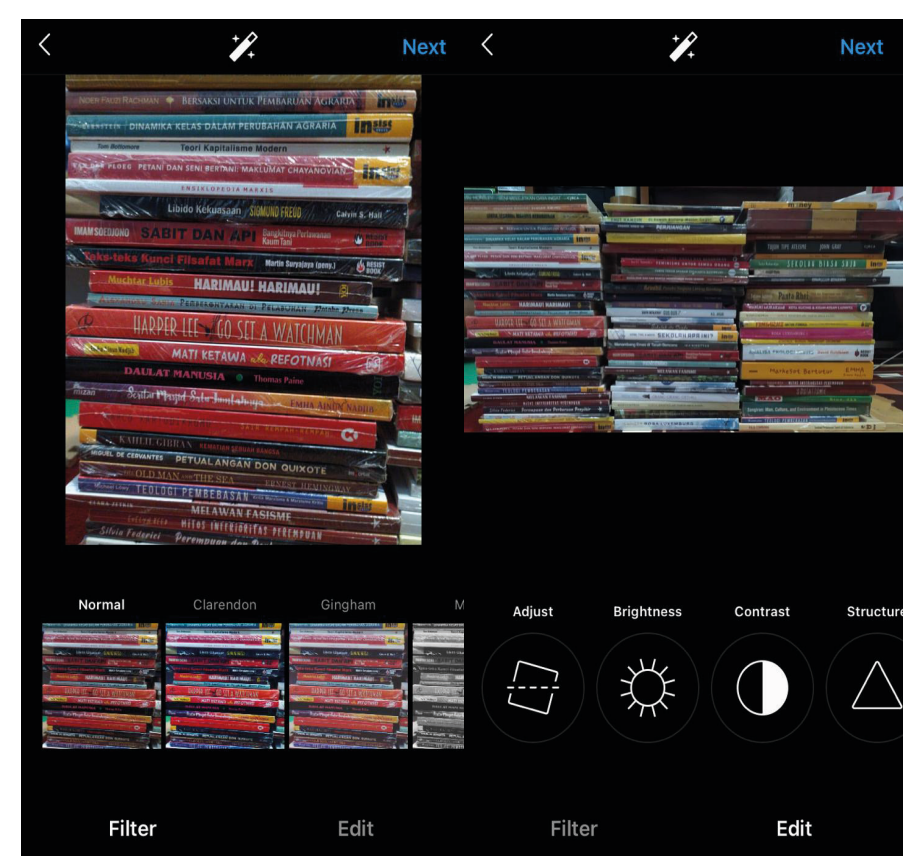

Figure 3.

Photo editing room on Instagram before upload Source: Personal data

Image posts from other accounts can also be saved to "collections" by other users. The two features are adjacent to the Love and Comment icons in Instagram's new look. In the previous version of the Instagram application, the icons Love and Comment included a description of the functions of the icons, namely "Like" and "Comment." The new Instagram application only shows a symbol without a description. This shows that the existing spaces on Instagram are now more diverse. The feature in the form of an icon shows that there are no limitations regarding the function of the feature. Uploaded photos can be commented on and liked by other users on the Instagram application. As a social media platform, Instagram can be a place to add friends by following other Instagram users. This act of following and being followed makes Instagram a space for social interaction. Social interaction does not only occur within the "likes" and "comments" on uploaded photos or videos. The uploaded image will appear in the follower's home space. Putting a "Love" on a photo or video that has been posted indicates that the uploaded photos and videos are considered to be beautiful, neat, and attractive. The more "likes" that there are on the uploaded photos and videos, the more that the photos and videos will continue to appear on the explore menu. Figure 4 shows the explore menu and how it is a feature on Instagram that will allow the users to find others.

The features on Instagram have changed to make it easier for the users to express themselves freely. Users can upload videos with a longer duration than the previous time limit. On Instagram, there is room allowing users to upload videos live on the Stories menu in the top left of the screen. The room is called "Instagram Live." When a user enters the Instagram Live room, they can interact directly with other users. Interactions on Instagram Live are like watching a show on a television screen. We can join the show through the option "Join Live" and provide love and comments on the screen. The maximum duration of an Instagram Live video is one hour. Instagram Live is a new feature on Instagram with the aim of not limiting the duration of Instagram Stories and providing actual recordings.

Another feature is Instagram TV. Instagram TV is a new feature on Instagram that allows users to upload videos of a duration of more than one minute. As the name implies, Instagram TV displays videos and shows them indirectly with a long duration. They can be watched by other Instagram users after the 
video is uploaded. Unlike Instagram Live, it cannot be broadcast continuously because it will disappear by itself within 24 hours. Instagram TV will be saved on the feed of other Instagram users and it is lost only if the user deletes it. The feed is a space to display profiles along with any uploaded photos and video.

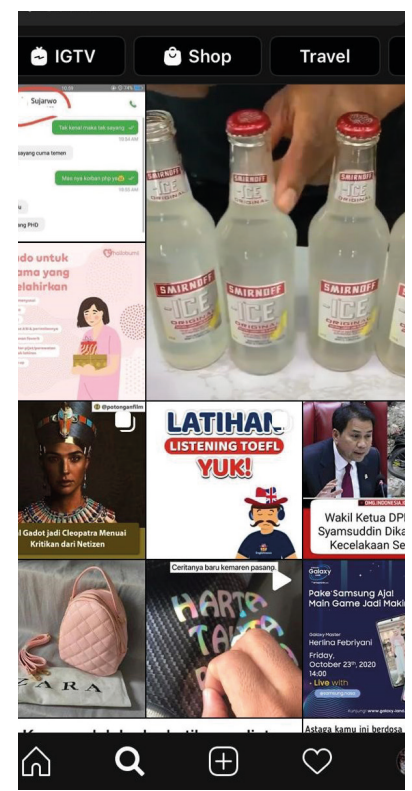

Figure 4.

Instagram's explore menu

Source: Personal data

Instagram can be understood to be a social media platform where there is an interaction virtually. The space is in the form of several "features" such as cameras, Instagram Stories, Instagram Live, highlights, the feed, filters, captions, Comment Room buttons, liking and saving photo or video posts, direct messaging, tagging and sharing, Instagram Live, Instagram TV and others. These kinds of features are not just "tools" or innovations. A virtual space intersects with real space when the application has been installed and it is functional in the real space, namely through the device. Users use the other functions of Instagram as a space to share moments and stories through both photos and videos. Before someone can use Instagram's features, they must first register themselves in order to have an account. After becoming registered, they then have a profile on Instagram. This profile is a bridge between the real world and the virtual world, and a profile of something that is not real (Lee \& Wei 2020).

The profile content is the result of curation by the users (Papacharissi 2002; Donath \& Boyd 2004; Marwick \& Boyd 2011; Lee \& Wei 2020), unlike in the real world. The profile is a person's persona on social media, adjusting to the user's context (Zhao et al. 2013). For example, for a traveler, the profile content will be filled with travel activities. Regarding the other features on Instagram, it shifts the function of the social media platform to more than just a place to upload photos or videos. Instagram as a space means that the results of the uploads have mutual meanings that intersect with each other. This phenomenon was later referred to by Foucault as heterotopia.

\section{Other spaces on Instagram}

In order to know and experience the other spaces on Instagram, it is necessary to have an account. The beginnings of prospective Instagram users as subjects in the heterotopia is the need to register themselves. This method is used to make a representation of themselves in real space. After that, the subject becomes part of the community in the real space. The subjects can carry out activities in the real space by sharing or uploading photos or videos. However, the subjects never see Instagram as a space for either utopia or heterotopia. Social network users do not know each and every audience of their content. The users have only an imaginary audience that influences them when presenting. Since the intended audience may differ between the social media services, users often change the pattern and form of their posts based on the character of the service of each social network (Litt \& Hargittai 2016; Ljungberg 2020).

Instagram as a real space has a utopian space behind it. The utopian space in reference to Instagram is because it is not only used as a place to put photos and videos. It can be used as a discourse battle arena through the photos and videos posted on the user pages. The utopian space and real space mix together 
as if the utopian space is invisible. There is a discourse struggle for as long as Instagram is still there, hence the discourse exists in unreal spaces. If you use the concept of Foucault's utopia and dystopia and how they have been mixed on Instagram, this makes a heterotopia space (Foucault 2008).

There are six principles regarding heterotopia (Topinka 2010). These are crisis heterotopia, where heterotopia is not eliminated and makes it function in other ways. Heterotopia has the power to connect multiple spaces and conflicting locations in one real place. Heterotopia is partly characterized by chunks of time where other spaces are open and closed simultaneously. Heterotopias' function is increasingly illusory and continually refined. Foucault's first principle mentions crisis heterotopia, but crisis heterotopia gradually disappears.

According to Foucault, crisis heterotopia occurs in primitive societies. In modern society, its remains can still be found. The disappearance of crisis heterotopia can be replaced by aberration heterotopia (Foucault 2008). Activities on Instagram initially include the shared photos and videos. On the other hand, there is also the discourse behind the photos and videos that were shared. The existence of photos and videos displays the luxurious lives of teenagers as a form of deviating from the social norms and values in society, as one example (von Wachenfeldt 2021). This luxurious private life in reality does not need to be widely displayed. This form of personal life is displayed in the form of photos and videos uploaded to the account.

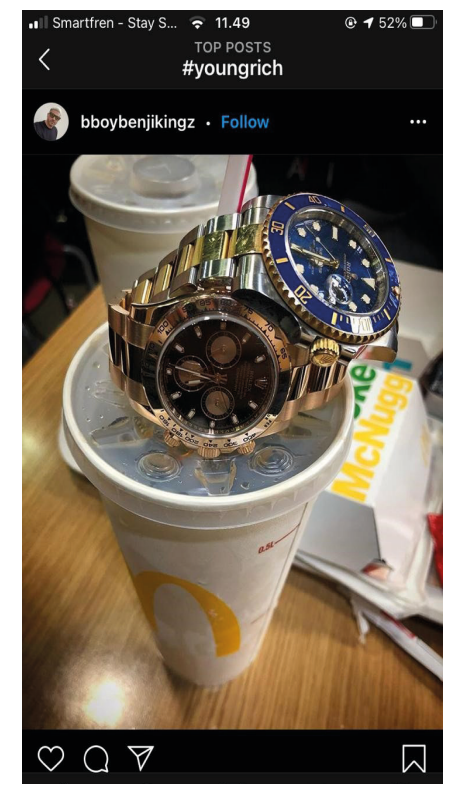

Figure 5.

A socialite on Instagram Source: Personal data

Irregularities in use of the Instagram application can be seen through the uploading of photos and videos on the subject's account. Posting on social media aims to show the existence of individuals in the real world. In order to be recognized by the environment, some uploading habits include luxury and arrogant behavior (Mahendra 2017). This method of mingling usually occurs between teenagers in urban areas. The high cost of the association forces teenagers to do anything to be recognized. Figure 5 shows that these users usually characterize or are characterized as socialites. Socialite use expensive branded goods and go to exclusive places (Pradhana 2019). Apart from wanting to be recognized by the environment, they also aim to increase the number of followers of their account. For adolescents, more followers than those who they follow means that they feel famous (Khamis et al. 2017). This can be done either intentionally or accidentally by most Instagram teen users. The more followers they have, the more that the user posts, making their activity widely spread. Space on Instagram strengthens the existence of the users, who are supported by various kinds of innovation on Instagram. The number of likes and comments on photo and video posts makes these posts popular. Having a large following on Instagram is a goal in order to prove the existence of the Instagram users.

Apart from the number of followers and likes on the posts, verified user accounts are also a sign that the owner of the account is an important figure. Account verification can be submitted through the "Account" menu. Account verification can be seen by the blue check icon that appears next to the Instagram account name. The blue check symbol indicates that the account is an original or verified account which includes 
prominent public figures, celebrities, global brands and represented entities (Boerman 2020). Requests for verified accounts are submitted by users on Instagram through the "Request Verification" menu, including their full name and what they are known for.

Then the user needs to select a category field to indicate the account focus. The account categories consist of news/media, sport, government/politics, music, fashion, entertainment, blogger/influencer, business/brand/organization, others. This category can be selected in the process of forming the identity and activity of the account, which will be verified later. Users also need to attach a governmentissued identification file as a condition for requesting verification of their Instagram account. Once sent, Instagram will consider the request. Not all users can have a verified account, even though they have made a request. The account verification icon certainly has a big impact on other users. With a blue check icon next to the account name, the Instagram account then gets more attention from others. Verified accounts are then known as celebrities or Instagram celebrities, which aims to strengthen the existence or influence of the figure behind the account (Boerman 2020).

Foucault's second principle suggests that heterotopia is not eliminated and makes it function in other ways. The initial function of Instagram was quite another thing in the midst of society early on. As time went on, the need to display the subject's presence increased and Instagram began to be flooded with users. In addition to acting as a place to put photos and videos to meet someone's existential needs, Instagram has been transformed into a space for economic activity and spreading propaganda (Lalancette \& Raynauld 2017; Zulli 2018). Innovation on Instagram is growing through the option to activate an Instagram account as either a personal account or a business account. A business account is a personal account transferred to a professional account. Professional accounts are used by users who want to access insights about their followers, account performance, new contact options and more. A professional account will make it easier for users to make promotions on Instagram and help them to reach more people. The contact option that you get on a professional account serves to make it easier for other users to contact them via the "contact" button on the profile.

Initially, the personal accounts were limited because there was a private menu. This type of account only shares things with their confirmed followers and provide access to view their profile. A professional account cannot be made private because it will then fail to increasingly reach a wide range of other users. The switch from a personal account to a professional account is done for free by selecting the corresponding account category. The categories include artists, musicians/bands, bloggers, clothing (brands), communities, digital creators, education, entrepreneurs, health/beauty, editors, authors, personal blogs, products/services, gamers, restaurants, beauty, cosmetics and care, grocery store, photographers, shopping and retail, and video creators.

Categories can be selected in order to describe the job or identity of the account owner. There will be the option for the account owner to show or hide the description of that category on their profile. This shows that Instagram today is not only a space for sharing photos or videos, but to show the work and identity of the user as well. Professional accounts have the function of spreading economic promotions widely. Many traders are used to offering their products through the platform. Apart from traders, professional accounts are used to spread their discourse widely so then they can influence their followers and other users.

The use and placement of space on Instagram continues to shift. In modern culture, Instagram has become a trending search engine. It can be consumed en-masse. In Kuwait, which is still influenced by its traditional culture, Instagram can affect daily activities. Those of the male gender are more likely to upload personal photos than women, as well as offering more personal information (Alkandari et al. 2016). However, it is undeniable that women can be more open about uploading photos and disclosing their personal information. As a result, there is the phenomenon of influencers on Instagram.

Influencers have become easy targets for the promotion of a product. The goal is to promote goods or services through influencers by the means of endorsements to reach a wider range of accounts so then they can penetrate the market. The hierarchy is clearly visible through this capitalistic economic model. This activity endorsement occurs on the account of a product that wants to collaborate with accounts that have a large number of followers. Accounts that have a large number of followers are considered to be trusted and verified accounts. The number of followers is used as a marketing target for the product that is to be offered (De Veirman et al. 2017). The merchant account will make a payment based on the contract rate of the nfluencer. The influencer will then receive the product and offer it through their Instagram account. This form of marketing is done by posting videos or photos of them consuming the product in an endorsement in accordance with the agreement or contract with the merchant. This activity of endorsement shows that Instagram is another space for a broader economic activity. 
The third principle offered for analyzing heterotopia is that heterotopia has the power to connect multiple spaces and conflicting locations in one real place. Foucault gave the example that parks are used as a form of city unification by various sides (Foucault 2008). Parks can also be used as a depiction of the symbols of the world in one place. Instagram brings together reality and the virtual world until there is no difference. Figure 6 shows that Instagram can be seen as a subject's memorable album, photo exhibition space, freelance portfolio and many other things through one platform (Scolere 2019). The unification of all forms of real activity today can be done virtually through Instagram. Instagram is more than just putting photos and videos on a page.

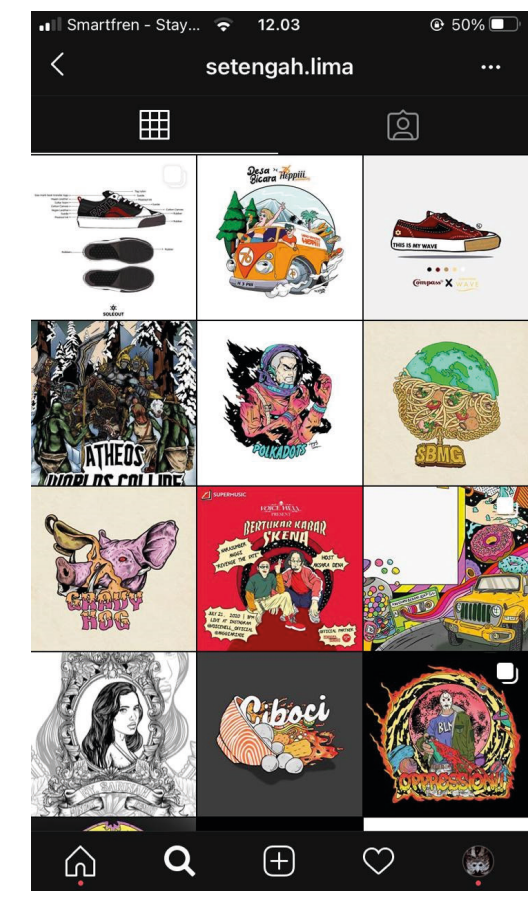

Figure 6.

Utilization of an Instagram account as a work portfolio Source: Personal data

Since Instagram was launched in 2010, the growth in the number of users has continued to increase. The increasing number of users is in line with the increasing number of activities that take place on Instagram as both a place and a variety of spaces. One of the spaces formed is a photo exhibition. Based on the shape, this photo exhibition is not as regular as other exhibitions. If there is a photo exhibition, it usually requires a photo critic. In contrast, on Instagram, everyone can criticize or praise the shots shared by an account. Likewise, on the matter of time, Instagram is used as an exhibition space with no time limit so long as the account owner does not delete the photo and other users do not block the account. The types of photos also vary.

There are eight categories of photo content determined through content grouping. The content categories are friends, food, captioned photo, pet, activity, selfies, and fashion (Hu et al. 2014). Furthermore, in the fourth principle, the heterotopia is partly characterized by chunks of time. Instagram includes time slices and pieces of its user's profiles (Rymarczuk \& Derksen 2014). It shows that there is a past, present, and future. A timeline is a collection of time that gets mixed up, becomes an accumulation of its own time. However, seeing the future on Instagram cannot be seen through the timeline. It can be seen through the photos and videos of an event agenda. It can also be seen in the form of digital event flyers. This form of timeline is a complex structured and ordered heterochronic form. The history of the digital subjects can be collected through the Instagram platform itself. This archive is only visible to the application administrator and to the owner of the application.

The appearance and method of working on Instagram is more or less similar to Facebook. The difference is that Facebook is basically an imitation of a community. Because Facebook bought Instagram in 2012, of course the features are similar even though they both have their own respective advantages and disadvantages. However, in principle, the difference between the two applications is not too striking as they are a collection of real time. Instagram is able to collect in detail the time that an event happens in order to remind us of the events at that time later on. This is in line with Foucault's thought on 
the principle of the fourth heterotopia. Instagram is like a library or museum in that time never stops accumulating (Lord 2006; Foucault 2008). Instagram reminds us that the shared moments are a form of celebration like a festival, with the aim that they can be shared again in the future. Instagram incarnates as time, although it occasionally incarnates as an alarm to share the memory of the account owner. This is because Instagram is a global archive of the world's individual memories, transcending time and penetrating the ages. All forms and all tastes in places of time are placed independently of time and are indestructible, eternal, and without limits (Foucault 2008).

The fifth heterotopia principle is that other spaces are open and closed simultaneously. All social media is like that, and Instagram is among them. Instagram requires every subject to register in order to engage in digital activity. In addition, there is a payment feature when using the photo promotion feature extensively. Registration and the promotional payment features are portal barriers between those who are allowed to access and those who are prohibited from accessing. Instagram also has a domain between the public and private in the settings. The goal is to limit other people from being able to see the photos and videos that are placed on a user's profile timeline. These settings can still be seen by Instagram's application administrators and the account owners. The application looks as thought it is open but it is actually exclusive. In addition, the latest features on Instagram have limits according to the choice of the account owner. This feature is called 'Close Friend'. Close Friend refers to a list of close friends who have been given permission by the account owner to view and comment on the story. This happens when the Instagram users activate the feature. The result is that the story can be seen by the users who are on the associated list.

Instagram and other social media are exclusive because they require a device and access in some form to an internet quota. This is often accessed by purchasing it from a service provider. Therefore not all people are able to access Instagram, even though Instagram seems to be fully open otherwise. The gaps in the access to the digital world are still a major factor generally. Rural and urban communities in Indonesia, according to Indicators Communication Technology (ICT), consist of households who are able to access the internet by only $26.3 \%$ and $48.5 \%$ respectively (Hadi 2018). Not even half of the total population in Indonesia is able to access the internet, according to these statistics. The main factor causing this gap is the availability of computer facilities and the internet connection connectivity (Warschauer 2003). The lack of access is also caused by low wages, meaning that the amount of capital owned by each household is not enough to pay for reach it (van Dijk 2014).

The culture of the Indonesian people is not yet accustomed to interacting when using social media. Interacting in the digital world is not a part of society itself. Today's digital world is an important part of people's lives. This means that through social media, individuals can manage their social relationships and engage in symbolic activities as and alongside social interactions. Social media can act as a bridge for individuals and communities to make their social interactions easier (Woodward 2007). People do not see these limitations as carrying out their social functions. In the last principle, Foucault offers seeing heterotopia, namely by seeing heterotopias' function as increasingly illusory and continually refined. Illusions that seem to represent reality are capable of creating real space. Even though something that looks real from the heterotopic perspective, it is an unreality compared to real space. Instagram, for a certain period of time, is continuously updating its application, regardless of the appropriateness of the performance of the application or the features in it. The result is that the illusions of the representation of the subject that can be seen by the other subjects are shown as real.

Every photo and video can be interpreted as a representation of the account owner. The Instagram 'Story' feature allows us to see daily representations of the account owner for 24 hours. Other features such as a blue tick on a profile indicates "special" people in the community, such as artists or public figures in the community. Profiles with blue ticks can be accessed and opened at any time. The utility is clear, indicating that we can communicate directly with the public figures. However, in reality, these accounts are often not personally controlled by the public figures but instead by administrators employed by the public figures.

Foucault gave the example of a brothel. According to him, the illusionary space presents itself in every real space in human life which is partitioned as an illusion (Foucault 2008). This mixing of spaces presents the illusion of Instagram space through personal profiles where uploading the latest photos or videos is an individual reality. However, each upload does not accurately represent the reality of the user. This kind of situation is similar to an individual's daily life which is often regulated by a clock. The clock binds the individual activities from morning to night. The clock does not represent real time. The clock only represents the time and use of time that relates to the freedom of the individual. 


\section{Conclusion}

This conclusion is based on the results of the analysis above, in that the heterotopia principles on Instagram are fulfilled. Instagram can be analyzed using Foucault's six principles of heterotopia. A place generates more than one space after being used by the user. Instagram is no longer just a place to share photos and videos. It can also be used for other activities which contain a discourse of their own and can be interpreted based on the shift in activity. Place changes its meaning as a result of the dynamics of the overlapping spaces. Instagram as a real space becomes biased because of the heterotopia present. Individuals interpret Instagram as a place to share, even when o the contrary, individuals also engage in other activities. They starting to demonstrate their existence in their environment by presenting illusions when interacting with people who have power. Instagram has changed its space due to a shift in place use. Instagram can create other spaces besides it is original function of uploading photos or videos through the other features on Instagram.

\section{References}

Abbott W, Donaghey J, Hare J \& Hopkins PJ (2013) An Instagram is worth a thousand words: An industry panel and audience Q\&A. Library Hi Tech News 30 (7):1-6.

Akmal HA \& Coulton P (2018) Using heterotopias to characterise interactions in physical/digital spaces. Design Research Social Conference 1:269-278. doi:10.21606/dma.2017.348.

Alkandari AJ, Al-Hunaiyyan AA \& Alhajri R (2016) The influence on Instagram use. Advances in Informartion Technology 7 (1):54-57.

Boerman SC (2019) The effects of the standardized instagram disclosure for micro-andmeso-influencers. Computers in Human Behavior. doi:10.1016/j.chb.2019.09.015.

Carpenter JP, Morrison SA, Craft M \& Lee M (2020) How and why are educators using Instagram? Teaching and Teacher Education 96:103149.

Castro DJV, Tvedebrink TDO \& Albeniz IM (2018) The Heterotopias of Food: Spaces and (Other) Places in Food Practices. In: Bonacho R, de Sousa AP, Viegas C, Martins JP, Pires MJ \& Estêvão SV (ed). Experiencing Food, Designing Dialogues. London: Taylor and Francis Group.

Damajani D (2008) Gejala ruang ketiga (thirdspace) di Kota Bandung: Paradoks dalam ruang publik urban kontemporer. Disertasi Program Doktor, Institut Teknologi Bandung, Bandung.

De Veirman M, Cauberghe V \& Hudders L (2017) Marketing through Instagram influencers: The impact of number of followers and product divergence on brand attitude. International Journal of Advertising 36 (5):798-828.

Donath J \& Boyd D (2004) Public displays of connection. BT Technology Journal 22 (4):71-82.

Feng X (2005) Internet and reality. Journal of China Youth College Political Sciences 2.

Foucault M (2008) Of Other Space. In: Dehaene M, Cauter L De (ed). Heterotopia and the City Public Space in a Postcivil Society. New York: Routledge.

Foucault M (2012) Arkeologi Pengetahuan. Yogyakarta: IRCISOD.

Gee JP (2005) An Introduction to Discourse Analysis: Theory and Method. New York: Routledge.

Hadi A (2018) Bridging Indonesia's digital divide: Rural-urban linkages? Jurnal Ilmu Sosial dan Ilmu Politik 22 (1):17-33.

Hu Y, Manikonda L \& Kambhampati S (2014) What we Instagram: A first analysis of Instagram photo content and user types. In: Proceedings of The Eighth International AAAI Conference on Weblogs and Social Media. Michigan, 595-598.

Huang YT \& Su SF (2018) Motives for Instagram use and topics of interest among young adults. Future Internet 10 (77):1-12.

Jordan B (2009) Blurring boundaries: The "real" and the "virtual" in hybrid spaces. Human Organization 68 (2):181-193.

Karimkhani C, Connett J, Boyers L, Quest T \& Dellavalle RP (2014) Dermatology on Instagram. Dermatol Online Journal 20 (7):1-6.

Kawulich BB (2005) Participant observation as a data collection method. Forum: Qualitative Social Research 6 (2):1-28.

Khamis S, Ang L \&Welling R (2017) Self-branding, 'micro-celebrity' and the rise of social media influencers. Celebrity Studies 8 (2):191-208.

Kusuma K (2018) Activities of the cyber public relations of o chanel TV in promoting their company on the Instagram social media. American Journal Humanities Social Sciences Research 2 (9):50-56.

Lalancette M \& Raynauld V (2017) The power of political image: Justin Trudeau, Instagram, and celebrity politics. American Behavioral Scientist 63 (7):888-924.

Lee KS \& Wei H (2020) Social media as Heterotopia: Applying Foucault's concept of heterotopia to analyze interventions in social media as a networked public. Archives of Design Research 33 (2):5-17. 
Litt E \& Hargittai E (2016) The imagined audience on social network sites. Social Media + Society 2 (1):1-12.

Ljungberg E (2020) Media practices in the making of an "other space": Communicating inclusion, exclusion, and belonging in a controversial heterotopia. New Media \& Society 22 (12):21662182.

Lord B (2006) Foucault's museum: Difference, representation, and genealogy. Museum and society 4 (1):11-14.

Mahendra B (2017) Eksistensi sosial remaja dalam Instagram (sebuah perspektif komunikasi). Jurnal Visi Komunikasi 16 (1):151-160.

Marwick AE \& Boyd D (2011) I tweet honestly, I tweet passionately: Twitter users, context collapse, and the imagined audience. New Media \& Society 13 (1):114-133.

Moleong LJ (2003) Metode Penelitian Kualitatif. Bandung: CV Remaja Rosdakarya.

Monita R (2010) Heterotopia pada Ruang Keseharian Studi Kasus: Plaza Indonesia. University of Indonesia.

Papacharissi Z (2002) The presentation of self in virtual life: Characteristics of personal home pages. Journalism \& Mass Communication Quarterly 79 (3):643-660.

Pradhana TA (2019) Self presenting pada media sosial Instagram dalam tinjauan teori dramaturgi Erving Goffman (studi pada mahasiswa UIN Sunan Ampel Surabaya). Thesis, UIN Sunan Ampel, Surabaya.

Rymarczuk R \& Derksen M (2014) Different spaces: Exploring Facebook as heterotopia. First Monday $19(6)$.

Salomon D (2013) Moving on from Facebook: Using Instagram to connect with undergraduates and engage in teaching and learning. ACRL TechConnect 74 (8):408-412.

Scolere L (2019) Brand yourself, design your future: Portfolio-building in the social media age. New Media \& Society 21 (9):1891-1909.

Sudrajat I (2012) Conceptualizing a framework for research on place in Indonesia. In: The First International Seminar on Place Making and Identity, Rethinking Urban Approaches to Built Environment, 26-27 September 2012, Tangerang. Indonesia: The First International Seminar on Place Making and Identity, Rethinking Urban Approaches to Built Environment.

Topinka RJ (2010) Foucault, Borges, heterotopia: Producing knowledge in other spaces. Foucault Studies 9 (1):54-70.

Tuan YF (1977) Space and Place: The Perspective of Experience. Minneapolis, MN: University of Minnesota Press.

van Dijk JAG (2014) The evolution of the digital divide: The digital divide turns into inequality of skills and usage. New Media \& Society 16 (3):507-526.

von Wachenfeldt P (2021) The mediation of luxury brands in digital storytelling. Fashion Theory 25 (1):99-118.

Warschauer M (2003) Technology and Social Inclusion: Rethinking the Digital Divide. Cambridge: MIT Press.

Woodward I (2007) Understanding Material Culture. London: Sage Publications.

Zhao X, Salehi N, Naranjit S, Alwaalan S, Voida S \& Cosley D (2013) The many faces of Facebook: Experiencing social media as performance, exhibition, and personal archive. In: Proceedings of the SIGCHI Conference on Human Factors in Computing Systems. doi: 10.1145/2470654.2470656.

Zulli D (2018) Capitalizing on the look: Insights into the glance, attention economy, and Instagram. Critical Studies in Media Communication 35 (2):137-150. 